\title{
Development of Kinetic Models Describing Kinetic Behavior of Bacillus cereus and Staphylococcus aureus in Milk
}

\author{
Hyoun Wook Kim, Sun-Ah Lee ${ }^{1}$, Yohan Yoon ${ }^{1}$, Hyun-Dong Paik², Jun-Sang Ham, Sang-Ha Han, Kuk-Hwan \\ Seol, Aera Jang ${ }^{3}$, Bum-Young Park, and Mi-Hwa Oh* \\ National Institute of Animal Science, Rural development Administration, Suwon 441-706, Korea \\ ${ }^{1}$ Department of Food and Nutrition, Sookmyung Women's University, Seoul 140-742, Korea \\ ${ }^{2}$ Department of Food Science and Biotechnology of Animal Resource, Konkuk University, Seoul 143-701, Korea \\ ${ }^{3}$ Department of Animal Products and Food Science, Kangwon National University, Chuncheon 200-701, Korea
}

\begin{abstract}
This study developed predictive models to evaluate the kinetic behaviors of Bacillus cereus and Staphylococcus aureus in milk during storage at various temperatures. B. cereus and $S$. aureus ( $3 \mathrm{Log} \mathrm{CFU} / \mathrm{mL}$ ) were inoculated into milk and stored at $10^{\circ} \mathrm{C}, 15^{\circ} \mathrm{C}, 20^{\circ} \mathrm{C}$, and $30^{\circ} \mathrm{C}$, as well as $5^{\circ} \mathrm{C}, 15^{\circ} \mathrm{C}, 25^{\circ} \mathrm{C}$, and $35^{\circ} \mathrm{C}$, respectively, while bacterial populations were enumerated. The growth data were fitted to the modified Gompertz model to estimate kinetic parameters, including the maximum specific growth rate $\left(\mu_{\max } ; \log \mathrm{CFU} /[\mathrm{mL} \cdot \mathrm{h}]\right)$, lag phase duration (LPD; h), lower asymptote $\left(N_{0} ; \log \mathrm{CFU} / \mathrm{mL}\right)$, and upper asymptote $\left(N_{\max } ; \log \mathrm{CFU} / \mathrm{mL}\right)$. To describe the kinetic behavior of B. cereus and S. aureus, the parameters were fitted to the square root model as a function of storage temperature. Finally, the developed models were validated with the observed data, and Bias $(B)$ and Accuracy $(A)$ factors were calculated. Cell counts of both bacteria increased with storage time. Primary modeling yielded the following parameters; $\mu_{\max }: 0.14-0.75$ and $0.06-0.51 \mathrm{Log}$ CFU $/ \mathrm{mL} / \mathrm{h} ; \mathrm{LPD}: 1.78-14.03$ and 0.00-1.44 h, $N_{0}: 3.10-3.37$ and 2.09-3.07 Log CFU/mL, and $N_{\max }: 7.59-8.87$ and 8.60-9.32 Log CFU/mL for B. cereus and $S$. aureus, respectively. Secondary modeling yielded a determination of coefficient $\left(R^{2}\right)$ of $0.926-0.996 . B$ factors were 1.20 and 0.94 , and $A$ factors were 1.16 and 1.08 for $B$. cereus and $S$. aureus, respectively. Thus, the mathematical models developed here should be useful in describing the kinetic behaviors of $B$. cereus and $S$. aureus in milk during storage.
\end{abstract}

Key words: Bacillus cereus, Staphylococcus aureus, milk, modified Gompertz model

\section{Introduction}

Milk is not only well-known nutritious foodstuff for humans but also an excellent matrix that facilitates growth of many types of microbes. For this reason, milk has received much attention, because it may serve as a vehicle for disease agents (Klein, 1901). In fact, raw milk often contains microorganisms that may cause food-borne diseases (Adesiyun et al., 1995; Headrick et al., 1998; Steele et al., 1997). Therefore, in most countries, restrictions and legislation regulating the marketing of unpasteurized milk have been introduced to minimize health risks associated with milk products (European Commission, 2000). However, these do not ensure the safety and quality of dairy products, because diseases associated

\footnotetext{
*Corresponding author: Mi-Hwa Oh, National Institute of Animal Science, Rural Development Administration, Suwon 441-706, Korea. Tel: 82-31-290-1689, Fax: 82-31-290-1697, E-mail: moh@korea.kr
}

with milk could occur because of insufficient pasteurization and/or cross-contamination (Altekruse et al., 1998; da Silva et al., 1998; Gran et al., 2003). Moreover, even though the heating process is sufficient to kill vegetative microorganisms, this treatment may be inadequate to remove microbial spores and toxins, such as Bacillus cereus and Staphylococcus aureus (Rall et al., 2008; Zwietering et al., 1996). Therefore, attention should also be focused on the management of dairy products after pasteurization. Therefore, attention should also be focused on the management of dairy products after pasteurization.

Microbiological challenge tests have been used for determining food safety related to spoilage and pathogenic microorganisms. Simulation of challenge tests should consider the effect of environmental conditions on food, including temperature, $\mathrm{pH}$, and water activity, that could affect the growth and proliferation of microorganisms (Roberts, 1997). Even though challenge tests have been thought to provide general assurance of food safety in the supply chain (Baranyi and Roberts, 1995; Noter- 
mans and in't Veld, 1994; Roberts, 1997), they have limitations: these tests are expensive, labor intensive, time consuming, and non-cumulative as a research tool (McDonald and Sun, 1999). Because of the limitations of challenge tests and the desire for safe, wholesome foods in the supply chain, predictive microbiology has been developed as a relatively new discipline (McMeekin et al., 1993).

The objective of this study was to develop mathematical models to describe the kinetic behaviors of B. cereus and $S$. aureus in milk under various storage conditions, which could affect their growth and proliferation.

\section{Materials and Methods}

\section{Bacterial strains and sample preparation}

Milk was purchased from a supermarket in Seoul, Korea. The milk was transported to the laboratory at low temperatures $\left(<7^{\circ} \mathrm{C}\right)$, stored at $4^{\circ} \mathrm{C}$, and analyzed within $24 \mathrm{~h}$. The inoculums consisted of B. cereus KCCM40935 and $S$. aureus KCCM12193, obtained from the Korea Culture Center of Microorganisms (KCCM, Korea). Each strain was pre-cultured in $10 \mathrm{~mL}$ of tryptic soy broth (TSB, Difco, USA) at $35^{\circ} \mathrm{C}$ at $24 \mathrm{~h}$. Diluted cell suspensions that had been pre-cultured were added to milk at a volume ratio of $1: 100 \mathrm{~mL}$, resulting in initial inoculums of approximately $3 \mathrm{Log}$ colony-forming units $(\mathrm{CFU}) / \mathrm{mL}$. Samples were then stored at $10^{\circ} \mathrm{C}, 15^{\circ} \mathrm{C}, 20^{\circ} \mathrm{C}$, or $30^{\circ} \mathrm{C}$ for $2 \mathrm{~d}(48 \mathrm{~h})$ for $\mathrm{B}$. cereus, and at $5^{\circ} \mathrm{C}, 15^{\circ} \mathrm{C}, 25^{\circ} \mathrm{C}$, or $35^{\circ} \mathrm{C}$ for $7 \mathrm{~d}(168 \mathrm{~h})$ for $S$. aureus, and the samples were taken for microbial growth measurements at regular intervals throughout the storage period.

\section{Microbial analysis}

To quantify the pathogenic bacteria in milk, B. cereus and $S$. aureus were enumerated throughout the storage period $(7 \mathrm{~d})$ at different temperatures $\left(\right.$ B. cereus: $10^{\circ} \mathrm{C}$, $15^{\circ} \mathrm{C}, 20^{\circ} \mathrm{C}$, or $30^{\circ} \mathrm{C} ; S$. aureus: $5^{\circ} \mathrm{C}, 15^{\circ} \mathrm{C}, 25^{\circ} \mathrm{C}$, or $35^{\circ} \mathrm{C}$ ). Preparation and microbial analyses were based on standard methods described in the FDA Bacteriological Analytical Manual (FDA, 2010). For each sampling, $10 \mathrm{~mL}$ of milk was aseptically transferred into a sterile bottle, and $90 \mathrm{~mL}$ of sterile $0.1 \%$ peptone water was added. The sample was homogenized for $1 \mathrm{~min}$, and aliquots were plated out directly, or as 10-fold dilutions in $0.1 \%$ peptone water. After serial dilution of each sample in sterile peptone water, $0.1 \mathrm{~mL}$ aliquot of each sample was separately plated onto each of 2 duplicate agar plates. Viable cells were evaluated by incubating inoculated tryptic soy agar (TSA, Difco, USA) at $35 \pm 2^{\circ} \mathrm{C}$ for $24 \pm$ $2 \mathrm{~h}$. After incubation, plates with 30-300 colonies were selected for counting. All analyses were performed 3 times, with 2 samples used for each replication, and counts were expressed as Log CFU per milliliter (Log $\mathrm{CFU} / \mathrm{mL})$.

\section{Primary model development}

Microbiological data $(\log C F U / \mathrm{ml})$ of $S$. aureus and $B$. cereus were fitted to the modified Gompertz model (Gibson et al., 1987). The modified Gompertz model is expressed as

$$
N_{t}=A+C \times \exp \{-\exp [-B(t-M)]\}
$$

where $N_{t}$ is the bacterial cell number at time $t(\mathrm{~h}), A$ is the initial cell number of the pathogens, $C$ is the difference between the upper asymptotic line of the growth curve and the lower asymptotic line, $B$ is the relative growth rate at time $M$, and $M$ is the time at which the growth rate is maximum (h). Maximum specific growth rate $\left(\mu_{\max } ; \log \mathrm{CFU} / \mathrm{ml} / \mathrm{h}\right)$, lag phage duration (LPD; $\mathrm{h}$ ), and $N_{\max }(\log \mathrm{CFU} / \mathrm{mL})$ were calculated by following equations

$$
\mu_{\max }=\frac{B C}{e}
$$

where $e$ is 2.7182 , and

$$
\begin{aligned}
& L P D=M-\frac{1}{B} \\
& N_{\max }=A+C
\end{aligned}
$$

\section{Secondary model development}

For $S$. aureus, $\mu_{\max }$ and LPD were fitted to the square root model and to a polynomial equation, respectively. The square root model is

$$
\sqrt{\mu_{\max }}=a_{\mu}\left(T-T_{\min }\right)
$$

where $a_{\mu}$ is the slope of the regression line for $\mu_{\max }$, and $T_{\min }$ is the theoretical minimum temperature $\left({ }^{\circ} \mathrm{C}\right)$. The polynomial equation is

$$
\sqrt{\frac{1}{L P D}}=a \times T^{2}+b \times T+c
$$

where $a, b$, and $c$ are regression parameters, and $T$ is the temperature $\left({ }^{\circ} \mathrm{C}\right)$.

For B. cereus, $\mu_{\max }$ and LPD were fitted to the square root model, and the power model was used for $N_{\max }$. As the $\mu_{\max }$ of $S$. aureus, square root model was used for 
$\sqrt{\mu_{\max }}$ of $B$. cereus, and the square root model for LPD is

$$
\sqrt{\frac{1}{L P D}}=a_{L P D}\left(T-T_{\min }\right)
$$

where $a_{\mathrm{LPD}}$ is the slope of the regression line for LPD. The power model equation is

$$
\sqrt{N_{\max }}=a \times T^{b}
$$

where $a$ and $b$ are regression parameters, and $T$ is the temperature $\left({ }^{\circ} \mathrm{C}\right)$.

\section{Model validation}

To validate the developed models, observed bacterial populations were compared to the predicted bacterial populations of the pathogen calculated from the simulation using the developed model (Jung and Lee, 2010; Medved'ová et al., 2009). The bias (B) and accuracy (A) factors were calculated as follows (Ross, 1996; Tamplin et al., 2005; Zhao et al., 2001). The $B$ factor shows whether the models over- or under-predict.

$$
\left.B \text { factor }=10^{[\Sigma \log (\text { predicted value/observed value })} n\right]
$$

The $A$ factor describes how close the predicted values are to the observed values,

$$
A \text { factor }=10^{[\Sigma \mid \log (\text { predicted value/observed value) } \mid / n]}
$$

where $n$ is the number of observed values. The value for perfect agreement between predicted values and observed values is 1 for both factors.

\section{Results and Discussion}

\section{Estimation of kinetic parameters}

During the storage of milk at $10^{\circ} \mathrm{C}, 15^{\circ} \mathrm{C}, 20^{\circ} \mathrm{C}$ and $30^{\circ} \mathrm{C}$ for $B$. cereus, and $5^{\circ} \mathrm{C}, 15^{\circ} \mathrm{C}, 25^{\circ} \mathrm{C}$ and $35^{\circ} \mathrm{C}$ for $S$. aureus, growths of these pathogens were observed at temperatures exceeding $15^{\circ} \mathrm{C}$. Hence, the growth data at $15^{\circ} \mathrm{C}, 25^{\circ} \mathrm{C}$, and $35^{\circ} \mathrm{C}$ for $S$. aureus were fitted to the modified Gompertz model; similarly, growth data of $B$. cereus at $15^{\circ} \mathrm{C}, 20^{\circ} \mathrm{C}$, and $30^{\circ} \mathrm{C}$ were analyzed using this model. In kinetic parameters for $S$. aureus, the differences of LPDs among storage temperatures were minimal, and $\mu_{\text {max }}$ values increased up to $0.51 \mathrm{Log} \mathrm{CFU} / \mathrm{mL} / \mathrm{h}$ as the storage temperature increased (Table 1). No effect of storage temperatures on $N_{0}$ values was observed, and thus no secondary model for $N_{0}$ was developed (Table 1). For $B$. cereus, longer LPD was observed at lower storage temperatures, and $\mu_{\max }$ values were also markedly increased up to $0.75 \mathrm{Log} C F U / \mathrm{mL} / \mathrm{h}$ (Table 2). As for $S$. aureus, $N_{0}$ values were not influenced by storage temperature, and thus, a secondary model was not developed for $N_{0}$ (Table 2). No increase of $N_{\max }$ with storage temperature was observed in $S$. aureus, but a correlation between $N_{\max }$ and storage temperature was observed in B. cereus, and thus $N_{\max }$ values were used for secondary modeling only for $B$. cereus. Because $R^{2}$ values were greater than 0.926 , regardless of storage temperature, and the predicted lines passed through most observed data (Tables 1 and 2, and Figs. 1 and 2), fitting of the growth data to the modified Gompertz model was considered acceptable.

Lag, exponential, and stationary phases in the bacterial growth curve could be influenced by food-related factors and/or environmental conditions (Medved'ová et al., 2009). Especially, Baranyi and Roberts (1995) demonstrated that the LPD is a period of adaptation to the environment while the intracellular conditions change. Dens et al. (2005) also suggested that medium, temperature, and physiological state of the cells were closely related to LPD. However, in our study, the increase in LPD by storage temperature was observed in B. cereus not in $S$. aureus (Tables 1 and 2). This finding indicates that LPD of $S$. aureus in milk may not be affected by storage tem-

Table 1. Kinetic parameters calculated by the Gompertz model for Staphylococcus aureus in milk

\begin{tabular}{cccccc}
\hline \hline Temperature $\left({ }^{\circ} \mathrm{C}\right)$ & LPD $(\mathrm{h})$ & $\mu_{\max }(\log \mathrm{CFU} / \mathrm{mL} / \mathrm{h})$ & $N_{0}(\log \mathrm{CFU} / \mathrm{mL})$ & $N_{\max }(\log \mathrm{CFU} / \mathrm{mL})$ & $R^{2}$ \\
\hline 15 & $0.00 \pm 0.00$ & $0.06 \pm 0.00$ & $2.58 \pm 0.30$ & $9.32 \pm 0.04$ & $0.966-0.969$ \\
25 & $1.17 \pm 2.02$ & $0.33 \pm 0.15$ & $2.09 \pm 0.56$ & $8.67 \pm 0.80$ & $0.926-0.990$ \\
35 & $1.44 \pm 0.16$ & $0.51 \pm 0.00$ & $3.07 \pm 0.09$ & $8.60 \pm 0.02$ & $0.945-0.948$ \\
\hline
\end{tabular}

LPD: lag phase duration, $\mu_{\max }$ : maximum specific growth rate, $N_{0}$ : lower asymptote, $N_{\max }$ : upper asymptote

Table 2. Kinetic parameters calculated by the Gompertz model for Bacillus cereus in milk

\begin{tabular}{cccccc}
\hline \hline Temperature $\left({ }^{\circ} \mathrm{C}\right)$ & LPD $(\mathrm{h})$ & $\mu_{\max }(\log$ CFU $/ \mathrm{mL} / \mathrm{h})$ & $N_{0}(\log$ CFU/mL) & $N_{\max }(\log$ CFU $/ \mathrm{mL})$ & $R^{2}$ \\
\hline 15 & $14.03 \pm 2.10$ & $0.14 \pm 0.00$ & $3.10 \pm 0.08$ & $7.59 \pm 0.09$ & $0.985-0.993$ \\
20 & $5.35 \pm 0.38$ & $0.35 \pm 0.03$ & $3.37 \pm 0.04$ & $8.70 \pm 0.03$ & $0.977-0.994$ \\
30 & $1.78 \pm 0.53$ & $0.75 \pm 0.11$ & $3.15 \pm 0.27$ & $8.87 \pm 0.06$ & $0.974-0.996$ \\
\hline
\end{tabular}

LPD: lag phase duration, $\mu_{\max }$ : maximum specific growth rate, $N_{0}$ : lower asymptote, $N_{\max }$ : upper asymptote 

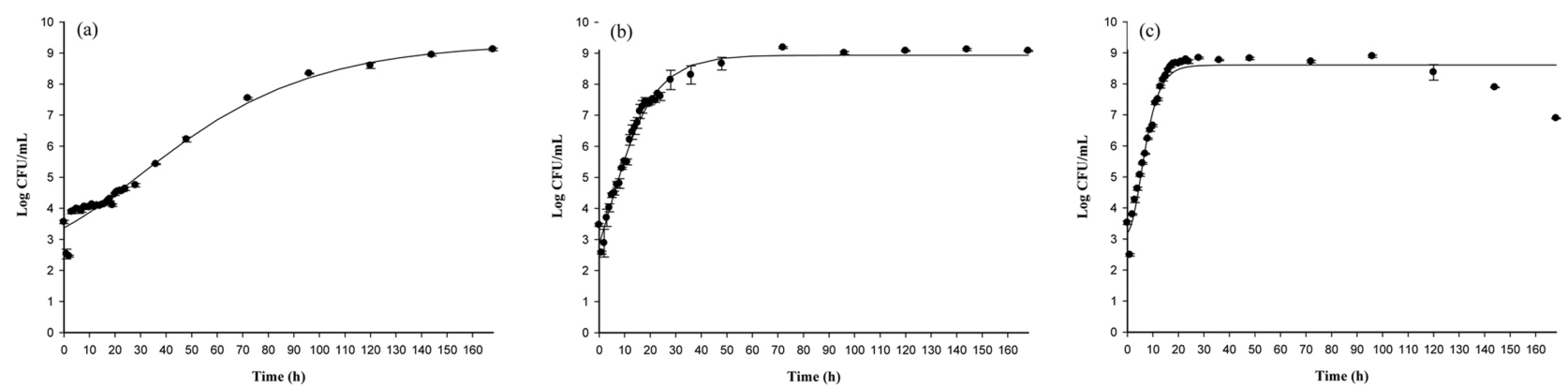

Fig. 1. Observed growth (symbol) and predicted growth (line) of Staphylococcus aureus in milk at $15^{\circ} \mathrm{C}(\mathrm{a}), 25^{\circ} \mathrm{C}(\mathrm{b})$, and $35^{\circ} \mathrm{C}(\mathrm{c})$ for $168 \mathrm{~h}$; the predicted line was produced by primary modeling with the Gompertz model.
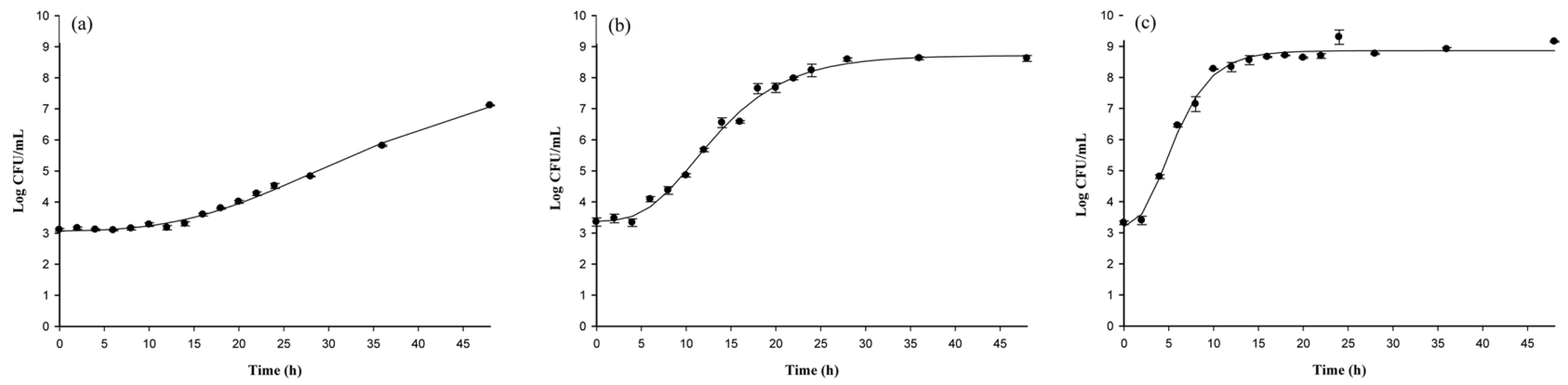

Fig. 2. Observed growth (symbol) and predicted growth (line) of Bacillus cereus in milk at $15^{\circ} \mathrm{C}(\mathrm{a}), 20^{\circ} \mathrm{C}(\mathrm{b})$, and $30^{\circ} \mathrm{C}(\mathrm{c})$ for $48 \mathrm{~h}$; the predicted line was produced by primary modeling with the Gompertz model.

perature.

\section{Secondary modeling}

To describe the kinetic behavior of $S$. aureus and $B$. cereus, the kinetic parameters, which were influenced by storage temperatures, were fitted to secondary models. Thus, although a secondary model for $N_{\max }$ of $S$. aureus in milk was not developed, secondary models for $\mu_{\text {max }}$, LPD, and $N_{\max }$ of B. cereus were developed as follows:

$$
\begin{aligned}
& \sqrt{\mu_{\max }}=0.0331(T-3.4108) \\
& \sqrt{\frac{1}{L P D}}=0.0329(T-6.8632) \\
& \sqrt{N_{\max }}=2.0333 \times T^{0.1153}
\end{aligned}
$$

In addition, secondary models describing the kinetic behavior of $S$. aureus in milk were developed as follows:

$$
\begin{aligned}
& \sqrt{\mu_{\max }}=0.0231(T-2.554113) \\
& \sqrt{\frac{1}{L P D}}=0.0024029 T^{2}-0.0783 T+0.6342
\end{aligned}
$$

The secondary models showed that the theoretical minimum temperatures for $B$. cereus and $S$. aureus growth were $3.42^{\circ} \mathrm{C}$ and $2.55^{\circ} \mathrm{C}$ in milk, respectively. A linear
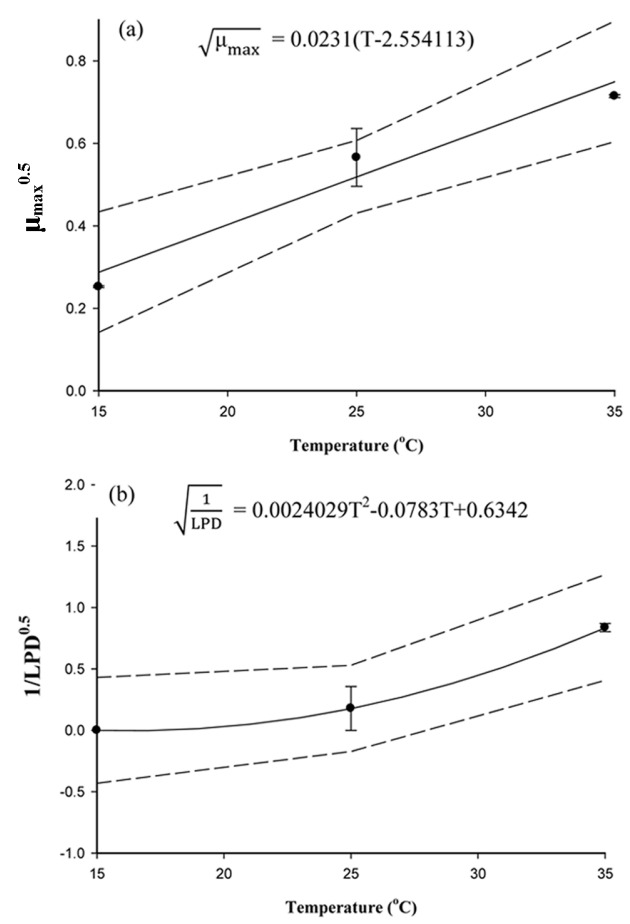

Fig. 3. The square root plot of $\mu_{\max }$ (a) and the polynomial plot of LPD (b) of Staphylococcus aureus in milk as a function of temperature. Symbols represent observed values; lines indicate predicted values according to the square root and the polynomial model; dashed lines indicate lower and upper $95 \%$ confidence intervals of the models. 

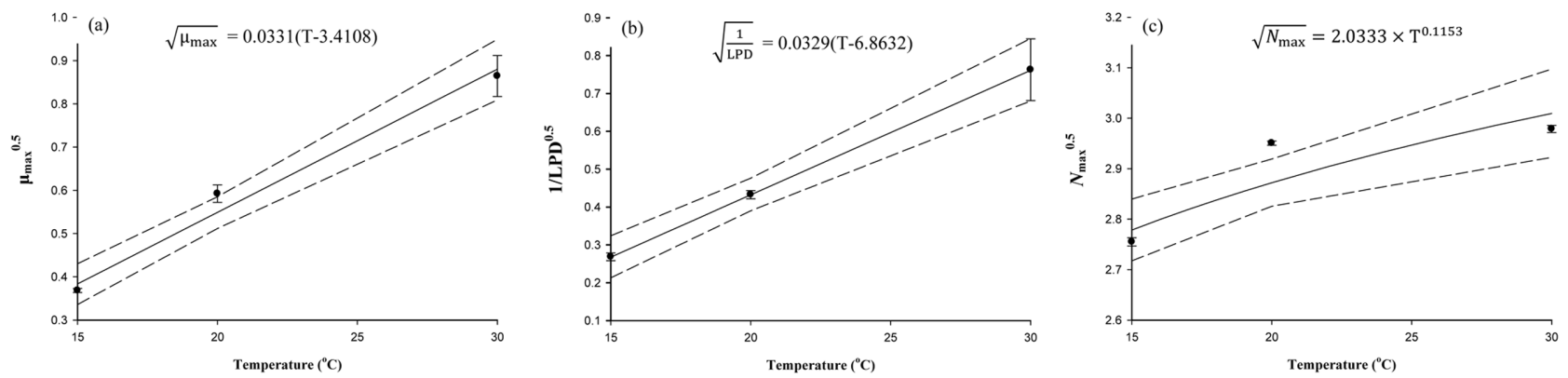

Fig. 4. The square root plot of $\mu_{\max }$ (a) and LPD (b), and the power plot of $N_{\max }$ (c) of Bacillus cereus in milk as a function of temperature. Symbols represent observed values; lines indicate predicted values according to the square root and the polynomial model; dashed lines indicate lower and upper $95 \%$ confidence intervals of the models.

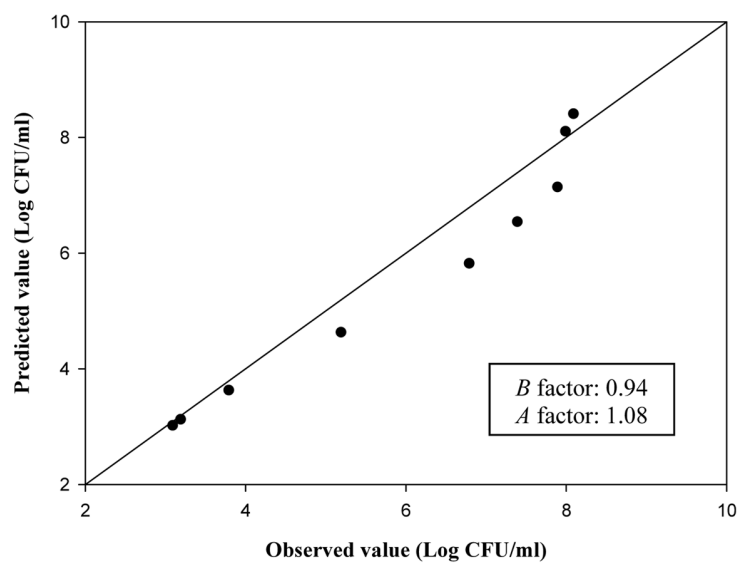

Fig. 5. Plots of observed Staphylococcus aureus cell counts against predicted Staphylococcus aureus cell counts in milk, after storage at $30^{\circ} \mathrm{C}$.

relationship between LPD and storage temperature was observed only for $B$. cereus in milk.

The $T_{\min }$ for $B$. cereus was in the range found in another study, viz., $9.15^{\circ} \mathrm{C}$ and $0.04^{\circ} \mathrm{C}$ in nutrient broth (Nauta et al., 2003). The variances of $T_{\min }$ values for B. cereus, including the $T_{\min }$ found in our study, may be caused by strain variation. For $T_{\min }$ of $S$. aureus, other studies have shown that the lowest $S$. aureus growth temperature was 6.5-7.0 ${ }^{\circ} \mathrm{C}$ (Asperger and Zangerl, 2003; Baird-Parker, 2000; Halpin-Dohnalek and Marth, 1989; Jay, 2000).

Medved'ová et al. (2009) evaluated the $T_{\min }$ values of 3 $S$. aureus strains in milk, and showed strain variation of $T_{\min }$ values $\left(4.89-7.02^{\circ} \mathrm{C}\right)$, which are slightly higher than the $T_{\min }$ calculated in our study. Thus, the lower $T_{\min }$ in our study may be caused by strain variation of $S$. aureus.

\section{Validation}

To validate model performance, the data from the studies by Jung and Lee (2010) and Medved'ová et al. (2009) were used as observed data. The observed data were compared with the predicted bacterial populations

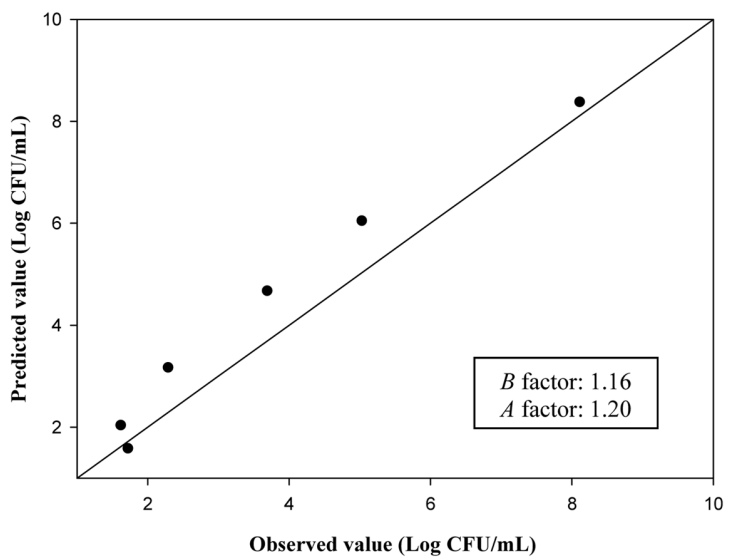

Fig. 6. Plots of observed Bacillus cereus cell counts against predicted Bacillus cereus cell counts in milk, after storage at $25^{\circ} \mathrm{C}$.

of $B$. cereus and $S$. aureus by using our model simulation, predicted values were plotted against observed values, and $B$ and $A$ factors were calculated. For $B$. cereus, the $B$ and $A$ factors were 0.94 and 1.08, respectively (Fig. 5), whereas those for $S$. aureus were 1.16 and 1.2 , respectively (Fig. 6). Perfect agreement between predicted and observed values should be 1 for both $B$ and $A$ factors (Ross et al., 2000). If the $B$ factor exceeds 1 , the model prediction is more than the true value, but if the $B$ factor is less than 1 , the predicted value is lower than the true value (Ross et al., 2000). For instance, the predictive model for B. cereus on average under-predicted by $6 \%$, whereas the model for $S$. aureus over-predicted by $16 \%$ in our study. Ross et al. (2000) suggested that a model yielding a $B$ factor of $0.7-0.9$ or $1.06-1.15$ is considered acceptable, whereas a model yielding a $B$ factor of $<0.7$ or $>1.5$ is considered unacceptable. The $A$ factor is a measure of average deviation, and this factor should be greater than 1; the higher this value, the less accurate the prediction (Ross, 1996; Yoon et al., 2009). The $A$ factors (1.08-1.2) in our study may suggest that the prediction by 
the developed model is accurate. Taken together, the predictive models developed in our study could be considered as having good predictive value.

In conclusion, the mathematical models developed here should be useful for describing the kinetic behaviors of $B$. cereus and $S$. aureus in milk during storage at various temperatures.

\section{Acknowledgements}

This work was carried out with the support of "Cooperactive Research Program for Agriculture Science and Technology Development" Rural Development Administration, Korea.

\section{References}

1. Adesiyun, A. A., Webb, L., and Rahaman, S. (1995) Microbiological quality of raw cow's milk at collection centers in Trinidad. J. Food Protect. 58, 139-146.

2. Altekruse, S. F., Timbo, B. B., Mowbray, J. C., Bean, N. H., and Potter, M. E. (1998) Cheese-associated outbreaks of human illness in the United States, 1973 to 1992: Sanitary manufacturing practices protect consumers. J. Food Protect. 61, 14051407.

3. Asperger, H. and Zangerl, P. (2002) Staphylococcus aureus. In: Encyclopaedia of dairy sciences. Roginski, H., Guquay, J. W., and Fox, P. F. (eds) Academic Press, San Diego, pp. 2563-2569.

4. Baird-Parker, T. C. (2000) Staphylococcus aureus. In: The microbiological safety and quality of food. Lund, B., BairdParker, A. C., and Gould, G. W. (eds) Aspen Publishers, Inc., Gaithersburg, pp. 1317-1330.

5. Baranyi, J. and Roberts, T. A. (1995) Mathematics of predictive food microbiology. Int. J. Food Microbiol. 26, 199-218.

6. da Silva, M. C., Hofer, E., and Tibana, A. (1998) Incidence of Listeria monocytogenes in cheese produced in Rio de Janeiro, Brazil. J. Food Protect. 61, 354-356.

7. Dens, E. J., Bernaerts, K., Standaert, A. R., and Van Impe, J. F. (2005) Cell division theory and individual-based modeling of microbial lag Part I. The theory of cell division. Int. J. Food Microbiol. 101, 303-318.

8. European Commission. (2000) Report on United States Barriers to trade and Investment. Bruessel, EU.

9. FDA (Food and Drug Administration). (2010) Bacteriological Analytical Manual. Available from: http://www.fda.gov/Food/ ScienceResearch/LaboratoryMethods/BacteriologicalAnalyticalManualBAM/default.htm. Accessed Jun. 30. 2010.

10. Gibson, A. M., Bratchell, N., and Roberts, T. A. (1987) The effect of sodium chloride and temperature on the rate and extent of growth of Clostridium botulinum type A in pasteurized pork slurry. J. Appl. Bacteriol. 62, 479-490.

11. Gran, H. M., Wetlesen, A., Mutukumira, A. N., Rukure, G., and Narvhus, J. A. (2003) Occurrence of pathogenic bacteria in raw milk, cultured pasteurized milk and naturally soured milk produced at small-scale dairies in Zimbabwe. Food Control 14, 539-544.

12. Halpin-Dohnalek, M. J. and Marth, E. H. (1989) Staphylococcus aureus: Production of extracellular compounds and behaviour in foods-a review. J. Food Protect. 52, 67-282.

13. Headrick, M. L., Korangy, S., Bean, N. H., Angulo, F. J., Altekruse, S. F., Potter, M. E., and Klontz, K. C. (1998) The epidemiology of raw milk-associated foodborne disease outbreaks reported in the United States, 1973 through 1992. Am. J. Public Health. 88, 1219-1221.

14. Jay, J. M. (2000) Staphylococcal gatroenteritis. In: Modern food microbiology. Jay, J. M., Loessner, M. J., and Golden, D. A. (ed) Aspen Publishers Inc., Gaithersburg, pp. 441-460.

15. Jung, J. H. and Lee, S. Y. (2010) Microbial growth in dry grain food (sunsik) beverages prepared with water, milk, soymilk, or honey-water. J. Food Sci. 75, M239-M242.

16. Klein, E. (1901) Pathogenic microbes in milk. J. Hyg. (Lond). 1, 78-95.

17. McDonals, K. and Sun, D. W. (1999) Predictive food microbiology for the meat industry: A review. Int. J. Food Mocrobiol. 52, 1-27.

18. McMeekin, T. A., Olley, J. N., Ross, T., and Rathowsky, D. A. (1993) Predictive microbiology: Theory and application. Research Studies Press Ltd., Taunton, Somerset.

19. Medved'ová, A., Valík, L', Sirotná, Z., and Liptáková, D. (2009) Growth characterization of Staphylococcus aureus in milk: a quantitative approach. Czech J. Food sci. 27, 443453.

20. Nauta, M. J., Litman, S., Barker, G. C., and Carlin, F. (2003) A retail and consumer phase model for exposure assessment of Bacillus cereus. Int. J. Food Microbiol. 83, 205-218.

21. Notermans, S. and in't Veld, P. (1994) Microbiological challenge testing for ensuring safety of food products. Int. J. Food Microbiol. 24, 33-39.

22. Rall, V. L. M., Vieira, F. P., Rall, R., Vieitis, R. L., Fernandes Jr., A., Candeias, J. M. G., Cardoso, K. F. G., and Araújo Jr., J. P. (2008) PCR detection of staphylococcal enterotoxin genes in Staphylococcus aureus strains isolated from raw and pasteurized milk. Vet. Microbiol. 132, 408-413.

23. Roberts, T. A. (1997) Microbial growth and survival: Developments in predictive modeling. Food Technol. 51, 88-90.

24. Ross, T. (1996) Indices for performance evaluation of predictive models in food microbiology. J. Appl. Bacteriol. 81, 501-508.

25. Ross. T., Dalgaard, P., and Tienungoon, S. (2000) Predictive modeling of the growth and survival of Listeria in fishery products. Int. J. Food Microbiol. 62, 231-245.

26. Steele, M. L., McNab, W. B., Poppe, C., Griffiths, M. W., Chen, S., Degrandis, S. A., Fruhner, L. C., Larkin, C. A., Lynch, J. A., and Odumeru, J. A. (1997) Survey of Ontario bulk tank raw milk for food-borne pathogens. J. Food Protect. 60, 1341-1346.

27. Tamplin, M. L., Paoli, G., Marmer, B. S., and Phillips, J. (2005) Models of the behavior of Escherichia coli O157:H7 in raw sterile ground beef stored at 5 to $46^{\circ} \mathrm{C}$. Int. J. Food Microbiol. 100, 335-344. 
28. Yoon, Y., Geornaras, I., Kendall, P. A., and Sofos, J. N. (2009) Modeling the effect of marination and temperature on Salmonella inactivation during drying of beef jerky. J. Food Sci. 74, M165-M171.

29. Zhao, L., Chen., Y., and Schaffner, D. W. (2001) Comparison of logistic regression and linear regression in modeling per- centage data. Appl. Environ. Microbiol. 67, 2129-2135.

30. Zwietering, M. H., de Wit, J. C., and Notermans, S. (1996) Application of predictive microbiology to estimate the number of Bacillus cereus in pasteurized milk at the point of consumption. Int. J. Food Microbiol. 30, 55-70.

$\overline{\text { (Received 2012.11.1/Revised 2013.2.6/Accepted 2013.3.19) }}$ 